\title{
An indigo-reducing moderate thermophile from a woad vat, Clostridium isatidis sp. nov.
}

\author{
A. Nikki Padden, ${ }^{1}$ Vivian M. Dillon, ${ }^{1}$ John Edmonds, ${ }^{2}$ M. David Collins, ${ }^{3} \dagger$ \\ Nerea Alvarez ${ }^{3}$ and Philip John ${ }^{1}$
}

Author for correspondence: A. Nikki Padden. Tel: +44118931 8098. Fax : +441189316577. e-mail: a.n.padden@reading.ac.uk

\author{
1 Department of \\ Agricultural Botany, \\ University of Reading, \\ Reading RG6 6AS, UK \\ 2 Chiltern Open Air \\ Museum, Chalfont St Giles \\ HP8 4AD, UK \\ 3 Department of \\ Microbiology, BBSRC \\ Institute of Food Research, \\ Reading Laboratory, \\ Reading RG6 6AP, UK
}

\begin{abstract}
A Gram-positive, anaerobic, moderate thermophile, strain Wv6', capable of reducing indigo dye, was isolated from a fermenting woad vat prepared essentially as in medieval Europe. Strain $\mathrm{Wv6}^{\top}$ formed rod-shaped cells, which occurred singly, in pairs or in chains and produced terminal oval endospores. Strain Wv6 ${ }^{\top}$ was saccharolytic. Growth occurred at pH 5.9-9.9 (initial pH) with an optimum at $50{ }^{\circ} \mathrm{C}$ of $\mathrm{pH} \mathrm{7.2 \pm 0.2}$ (constant pH). At pH 7.8, the temperature range for growth was $30-55{ }^{\circ} \mathrm{C}$ with the optimum at 49-52 ${ }^{\circ} \mathrm{C}$. Comparative $16 \mathrm{~S}$ rRNA gene sequence analysis demonstrated that the bacterium represents a hitherto unknown subline within rRNA cluster I Clostridium. Based on the results of the phylogenetic analysis and phenotypic criteria, it is proposed that the unknown moderate thermophile should be classified as Clostridium isatidis sp. nov., a new species of the genus Clostridium. The type strain of Clostridium isatidis is strain Wv6 ${ }^{\top}$ (= NCFB $\left.3071^{\top}\right)$.
\end{abstract}

Keywords: Clostridium isatidis sp. nov., phylogeny, indigo reduction, moderate thermophile

\section{INTRODUCTION}

Indigo is the only natural source of blue dye and its use dates back to the Neolithic period (Clark et al., 1993). Indigo produced from the woad plant (Isatis tinctoria L.) was used extensively in temperate regions during the Middle Ages. The leaves were routinely harvested in summer, crushed and the resulting paste kneaded into woad balls of about $10 \mathrm{~cm}$ diameter, which were air-dried. The dried woad balls could be stored indefinitely but before the woad could be used for dyeing it was 'couched'. In this process, the woad balls were crushed and wetted, encouraging aerobic microbial activity which increased the temperature to $55^{\circ} \mathrm{C}$. After approximately 2 weeks, the 'couched woad' was allowed to dry (Hurry, 1930). The woad was further processed in the woad vat, in which material to be dyed was immersed. Hot water was added to the couched woad and the vat was maintained at $50{ }^{\circ} \mathrm{C}$. During the ensuing fermentation, the $\mathrm{pH}$ was maintained alkaline by the periodic addition of potash

\footnotetext{
+Present address: Department of Food Science and Technology, University of Reading, Reading RG6 6AS, UK.

The GenBank accession number for the 16S rRNA gene sequence of strain $\mathrm{WV6}^{\top}\left(=\right.$ NCFB $\left.3071^{\top}\right)$ is $\mathrm{X} 98395$.
}

or lime. In the woad vat, the insoluble oxidized form of indigo was converted by reduction to the soluble colourless form, leuco-indigo. On exposure of the treated material to air it became re-oxidized and blue dyed.

The use of indigenous woad as a source of indigo declined in the early 17 th century when the import of natural indigo (Indigofera tinctoria) to Europe from India began (Clark et al., 1993). Natural indigo was capable of producing a much higher yield of the indigo pigment than woad could. In the late 19th century, production of synthetic indigo, a cheaper option that catered for increasing demand replaced the need for natural indigo. Currently wastewaters from the dyeing industry, which uses sodium dithionite as a reducing agent, are a burden to the environment (Kabdasli et al., 1995) and thus a natural alternative to dithionite would be desirable.

In this study, we report on an anaerobic moderate thermophile, isolated from a woad vat, which possesses the ability to reduce the oxidized insoluble form of indigo to the soluble reduced form. On the basis of phenotypic and molecular taxonomic data, a new species, Clostridium isatidis, is proposed for this bacterium. 


\section{METHODS}

Sample collection and bacterial enrichment. Couched woad was used as an inoculum for the woad vat. The woad was grown at the Chiltern Open Air Museum, Chalfont St Giles and at the University of Reading; the leaves were harvested in the summer of 1994 from woad sown in spring 1994. Harvested leaves were rolled into balls and dried. The woad balls were then couched for 2 weeks and allowed to dry. Boiling tap water $(500 \mathrm{ml})$ was added to the couched woad $(100 \mathrm{~g})$ and the vat was incubated in a water bath $\left(50^{\circ} \mathrm{C}\right)$ for up to $8 \mathrm{~d}$. The $\mathrm{pH}$ was maintained at $\mathrm{pH} 9.0 \pm 0.4$ with oak wood ash or $2 \mathrm{M} \mathrm{NaOH}$. The reference strain, Clostridium carnis (NCIMB $10670^{\mathrm{T}}$ ), was obtained from the National Collection of Industrial and Marine Bacteria, Aberdeen, UK. Indigo reduction was also tested for in Clostridium aurantibutyricum (DSM 793 ${ }^{\mathrm{T}}$ ), Clostridium celatum (DSM $1785^{\mathrm{T}}$ ) and Clostridium quinii (DSM 6736 $6^{\mathrm{T}}$ ), which were obtained from the Deutsche Sammlung von Mikroorganismen und Zellkulturen, Braunschweig, Germany.

Isolation. The bacterial populations of the woad vat were examined after $30 \mathrm{~h}$ and $8 \mathrm{~d}$ incubation. Samples were removed and diluted in peptone water $(0 \cdot 1 \%, \mathrm{w} / \mathrm{v})$ and then spread onto selective media, as follows: Reinforced Clostridium Agar (RCA), anaerobes; Dextrose Tryptone Media, thermophiles and mesophiles; Rose Bengal Chloramphenicol, yeasts and moulds; Violet Red Bile Glucose, enterobacteriaceae; and Plate Count Agar, viable organisms (Oxoid). The plates were incubated aerobically or anaerobically as appropriate for $3 \mathrm{~d}$ at $47^{\circ} \mathrm{C}$. Anaerobic incubations were carried out using a 3.51 polycarbonate anaerobic jar with an anaerobic gas generating system (Oxoid). The indigo-reducing bacteria were subsequently isolated using RCA supplemented with $0.01 \%$ (w/v) indigo, $\mathrm{pH}$ $9 \cdot 0 \pm 0 \cdot 2$, incubated anaerobically at $47^{\circ} \mathrm{C}$ for $24-48 \mathrm{~h}$.

Light microscopy. Light microscopy was performed using a Reichert Polyvar 2 (Leica). Fixed slides were stained with carbol fuchsin and viewed under bright field. A sample of culture grown on RCA and Reinforced Clostridial Medium (RCM) (Oxoid) was used.

Temperature and $\mathbf{p H}$ ranges. The temperature range was tested in static liquid batch culture using RCM, pH 7.8 $\pm 0 \cdot 2$ (test temperature). The cultures were incubated at the respective temperature and samples were taken at regular intervals. Growth rates were calculated using the increase in turbidity $\left(\mathrm{OD}_{600}\right)$. The $\mathrm{pH}$ range for growth was tested as above with an incubation temperature of $45^{\circ} \mathrm{C}$. The $\mathrm{pH}$ optimum was determined at $50^{\circ} \mathrm{C}$ using controlled-batch culture (Brighton Systems). The $\mathrm{pH}$ was controlled by automatic titration of $2 \mathrm{M} \mathrm{HCl}$ and $2 \mathrm{M} \mathrm{NaOH}$. Anaerobic conditions were maintained by flushing the culture with sterile oxygen-free nitrogen (BOC gases) between each run and the culture was stirred at 50 r.p.m. RCM without agar was used.

Substrate utilization. Growth on carbohydrates was determined using a modified PY broth ( $\mathrm{pH} \mathrm{8.0).} \mathrm{This} \mathrm{contained}$ $\left(1^{-1}\right.$ distilled water): peptone, $0.5 \mathrm{~g}$; tryptone, $0.5 \mathrm{~g}$; yeast extract, $1 \mathrm{~g}$; haemin solution $(50 \mathrm{mg}$ haemin dissolved in $1 \mathrm{ml} 1 \mathrm{M} \mathrm{NaOH}$, added to $99 \mathrm{ml}$ deionized water, autoclaved separately), $10 \mathrm{ml}$; vitamin $\mathrm{K}_{1}$ solution [0.15 ml vitamin $\mathrm{K}_{1}$ in $30 \mathrm{ml} 95 \%(\mathrm{v} / \mathrm{v})$ ethanol], $0.2 \mathrm{ml}$; cysteine. $\mathrm{HCl} . \mathrm{H}_{2} \mathrm{O}$, $0.5 \mathrm{~g}$; and salts solution, $40 \mathrm{ml}$. The salts solution contained ( $1^{-1}$ distilled water): $\mathrm{CaCl}_{2}, 0.2 \mathrm{~g} ; \mathrm{MgSO}_{4} .7 \mathrm{H}_{2} \mathrm{O}, 0.48 \mathrm{~g}$; $\mathrm{K}_{2} \mathrm{HPO}_{4}, 1.0 \mathrm{~g} ; \mathrm{KH}_{2} \mathrm{PO}_{4}, 1.0 \mathrm{~g} ; \mathrm{NaHCO}_{3}, 10.0 \mathrm{~g} ; \mathrm{NaCl}$, $2 \cdot 0 \mathrm{~g}$. All carbohydrate solutions were filter-sterilized, with the exception of glycerol and starch, which were autoclaved, and added to the medium at the final concentrations given below. Broths were incubated at $45^{\circ} \mathrm{C}$ for up to $48 \mathrm{~h}$ and the increase in turbidity at $600 \mathrm{~nm}$ was monitored. Cultures which exhibited an increase of at least $0 \cdot 1$ OD unit were considered positive for substrate utilization.

Biochemical tests. The following biochemical tests were carried out according to Harrigan \& McCance (1976): gelatin hydrolysis using nutrient agar plates supplemented with gelatin $\left(4 \mathrm{~g} \mathrm{l}^{-1}\right)$; production of $\alpha$-amylase and $\beta$-amylase using starch agar $(0.2 \%, \mathrm{w} / \mathrm{v})$; lecithinase activity in egg yolk agar using $10 \mathrm{ml}$ egg yolk emulsion (Oxoid) added to $100 \mathrm{ml}$ nutrient agar after autoclaving; the ability to clot milk in litmus milk ( $100 \mathrm{~g}$ skim milk powder $1^{-1}$ with $10 \mathrm{ml}$ $4 \%$ litmus solution (BDH Chemicals); the digestion of meat by the production of proteolytic enzymes in cooked meat medium (Oxoid); nitrate reduction in nitrate peptone water $\left(\mathrm{KNO}_{3}, 0.2 \mathrm{~g} \mathrm{l}^{-1}\right.$; peptone, $10 \mathrm{~g} \mathrm{l}^{-1}$; and agar, $0.3 \%$ ); haemolysis in $100 \mathrm{ml}$ blood agar base (Oxoid) supplemented with $5 \mathrm{ml}$ sheep blood and $5 \mathrm{ml}$ horse blood. To test for catalase, $1 \mathrm{ml} \mathrm{H}_{2} \mathrm{O}_{2}(10 \%, v / v)$ was poured onto fresh cultures and the presence of any oxygen bubbles was noted. Acid production, aesculin hydrolysis, indole production and urease were tested for using API 20A strips (bioMérieux), onto which the woad vat isolates and $C$. carnis were inoculated and incubated anaerobically at $37^{\circ} \mathrm{C}$ for $24 \mathrm{~h}$ (according to manufacturer's instructions). Additional tests for acid production were carried out using PY broth supplemented with Bromocresol Purple $\left(0.02 \mathrm{~g}^{-1}\right)$ as a $\mathrm{pH}$ indicator.

Susceptibility to antibiotics. Resistance to antibiotics was examined using liquid broth cultures containing filtersterilized antibiotics or Difco Dispence-O-Disc minifilters on RCA plates. An exponentially growing culture was inoculated $(5 \%, \mathrm{v} / \mathrm{v})$ into fresh RCM supplemented with the antibiotic and incubated at $45^{\circ} \mathrm{C}$ for $48 \mathrm{~h}$ or spread onto RCA plates and incubated anaerobically.

Fermentation products of PYG. The fermentation products were analysed after growth on a PYG medium containing $\left(1^{-1}\right.$ distilled water): peptone, $5 \mathrm{~g}$; tryptone, $5 \mathrm{~g}$; yeast extract, $10 \mathrm{~g}$; glucose, $10 \mathrm{~g}$; salts solution, $40 \mathrm{ml}$; haemin solution, $10 \mathrm{ml}$; vitamin $\mathrm{K}_{1}$ solution, $0.2 \mathrm{ml}$; and cysteine. $\mathrm{HCl} . \mathrm{H}_{2} \mathrm{O}, 0.5 \mathrm{~g}$. The cultures were incubated statically at $45^{\circ} \mathrm{C}$ at initial pH 8.0. Gases were determined by GC using a GCD chromatograph (Pye Unicam) equipped with a Porapak $\mathrm{R}$ column and a thermal conductivity detector. Organic acids were determined by HPLC using an Aminex HPX97H ion-exclusion column fitted with a guard column (Bio-Rad).

Determination of $\mathbf{G}+\mathbf{C}$ content. The $\mathrm{G}+\mathrm{C}$ content ( $\mathrm{mol} \%$ ) was determined by the thermal melting point method (Garvie, 1978) using DNA extracted from strain $\mathrm{Wv6}^{\mathrm{T}}$ grown on RCA.

165 rRNA gene sequence analysis. DNA was extracted by the method of Lawson et al. (1989). 16S rRNA gene fragments (corresponding to Escherichia coli positions 31-1521) were amplified by PCR, using primers for conserved sequences near the $5^{\prime}$ and $3^{\prime}$ ends of the gene (Boddinghaus et al., 1990). After purification with a Prep-A-Gene kit (Bio-Rad), the PCR products were sequenced using a DyeDeoxy Terminator Cycle Sequencing kit (Applied Biosystems) and a model 373A automatic DNA sequencer (Applied Biosystems). The FASTA program from the GCG package (Devereux et al., 1984) was used to identify the nearest 
relatives of the woad isolates. The $16 \mathrm{~S}$ rRNA sequences of these strains were then obtained from the EMBL and Ribosomal Database Project data libraries to be included in further analyses. Sequences were aligned by using the program PILEUP (Devereux et al., 1984) and the alignment was verified and corrected manually. Approximately the first 100 bases (which include variable region VI) were excluded from the phylogenetic analysis because of incomplete sequences for some strains and alignment uncertainties. A distance matrix was prepared using the programs PRETTY (Devereux et al., 1984) and DNADIST (Felsenstein, 1989) and a phylogenetic tree was derived from the distance data using the program NEIGHBOR (Felsenstein, 1989). The stability of the groupings was assessed by bootstrap analysis using the programs SEQBOOT (500 replications), DNADIST, NEIGHBOR and CONSENSE of the PHYLIP package (Felsenstein, 1989).

\section{RESULTS AND DISCUSSION}

\section{Isolation}

After $30 \mathrm{~h}$ incubation, the bacterial population of the woad vat consisted of both aerobic and anaerobic bacteria representing $10^{7}$ and $4 \times 10^{5}$ bacteria per $\mathrm{ml}$ slurry, respectively. After $8 \mathrm{~d}$, the number of aerobic (and/or facultative anaerobic) bacteria remained constant and consisted of at least four different bacterial types. Bacterial numbers were highest on the RCA plates. The anaerobic bacterial count increased to $3 \times 10^{6}$ bacteria per ml slurry (RCA plates) and consisted of 10 slightly different morphological types (denoted strains Wvl-Wv10). No yeasts or moulds were present at either stage during the enrichment. As indigo reduction occurred under anaerobic conditions at an alkali $\mathrm{pH}$, colonies were taken from the RCA plates and re-streaked onto $\mathrm{RCA}, \mathrm{pH} 9$, and incubated anaerobically at $47^{\circ} \mathrm{C}$. Five out of the 10 isolates grew well (strains Wv6 ${ }^{\mathrm{T}}-\mathrm{Wv} 10$ ) and were re-streaked onto RCA, pH 9, supplemented with $0.01 \%(\mathrm{w} / \mathrm{v})$ indigo. Indigo reduction was indicated by the medium going colourless under anaerobic incubation conditions, and becoming blue on exposure to air. All five isolates reduced indigo. The isolates were all catalase-negative, rod-shaped, Gram-positive bacteria, which produced oval terminal endospores. Colonial morphology of the isolates was identical on horse blood agar and no isolate could grow aerobically. Strains Wv6 ${ }^{\mathrm{T}}-\mathrm{Wv} 10$ were also shown to be genetically homogeneous (see below) and therefore strain $\mathrm{Wv}^{\mathrm{T}}$ was used as the representative strain which was maintained on RCA plates, $\mathrm{pH} 9 \cdot 0 \pm 0 \cdot 2$.

\section{Colony and cell morphology of strain $\mathrm{Wv}^{\top}$}

Strain $\mathrm{Wv} 6^{\mathrm{T}}$ produced creamy white mucoid colonies on RCA (pH $9 \cdot 0 \pm 0 \cdot 2$ ) up to $7 \mathrm{~mm}$ in diameter. Colonies were circular to irregular and low convex or were raised to a central point. On sheep and horse blood agar, colonies were grey and feathery and $2 \mathrm{~mm}$ in diameter. Slight $\beta$-haemolysis occurred on horse blood agar but not on sheep blood agar. Cells were rod-shaped and occurred singly, in pairs or in chains
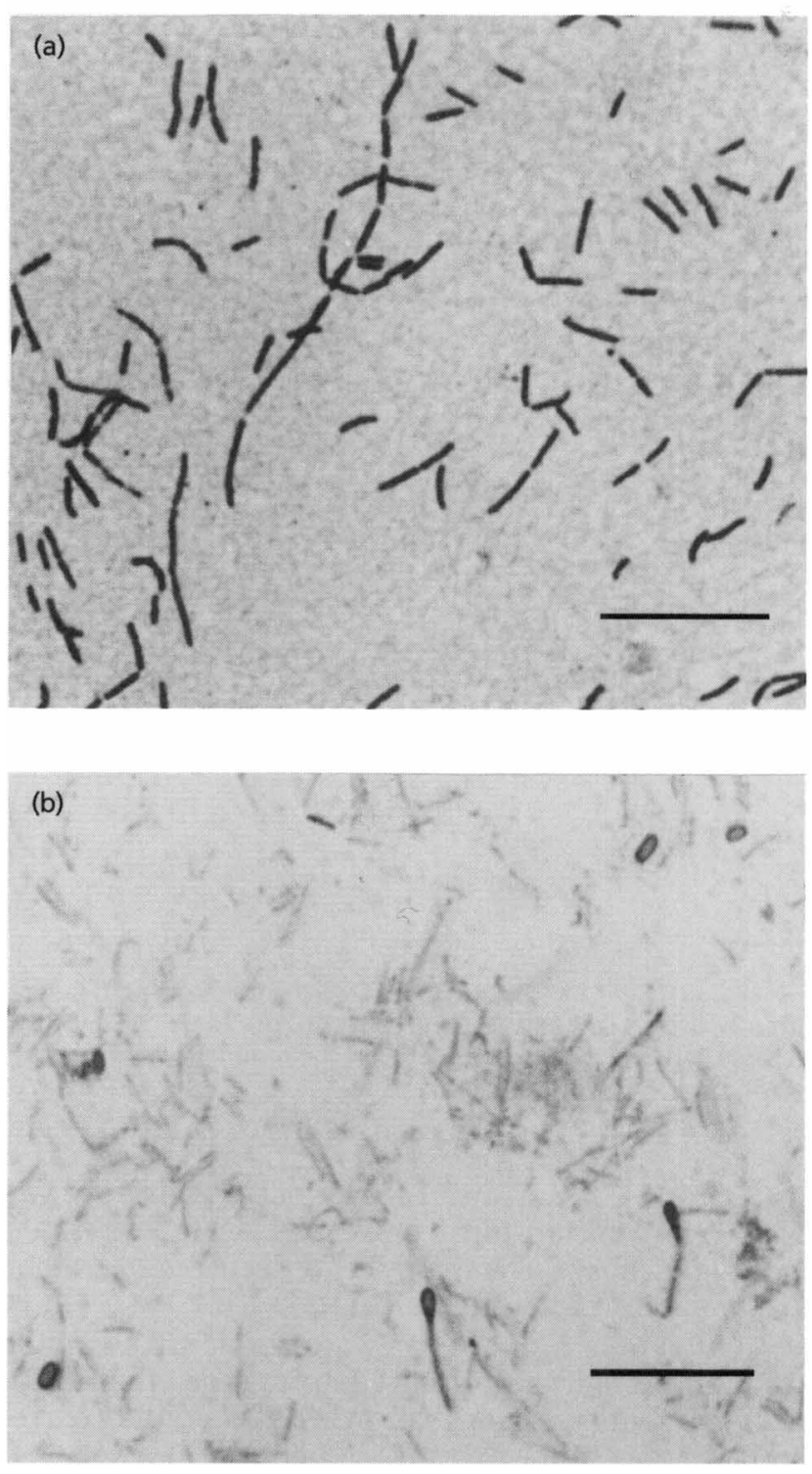

Fig. 1. Light micrographs of (a) vegetative cells grown in RCM after $6 \mathrm{~h}$ and (b) sporulated cells, mature spores and partially stained dead vegetative cells of strain $W v 6^{\top}$ grown on RCA plates after $48 \mathrm{~h}$. Bar, $10 \mu \mathrm{m}$.

(Fig. 1a). The rods were $0 \cdot 3-0 \cdot 6 \mu \mathrm{m}$ by $1 \cdot 8-9 \cdot 1 \mu \mathrm{m}$. Oval terminal endospores were produced in both liquid and solid batch culture at late exponential or early stationary phase (Fig. 1b). When grown in RCM, pH $8 \cdot 6$, spores could withstand heat treatment of $90^{\circ} \mathrm{C}$ for $10 \mathrm{~min}$ but were killed after exposure to $100^{\circ} \mathrm{C}$ for 4 min. Cells exhibited a tumbling motility at all stages of growth.

\section{Biochemical and physiological characteristics}

(i) Growth requirements. Strain $\mathrm{Wv} 6^{\mathrm{T}}$ was incapable of growth in air on RCA (or blood agar) plates, but was aerotolerant and remained viable after 3 months 
(a)

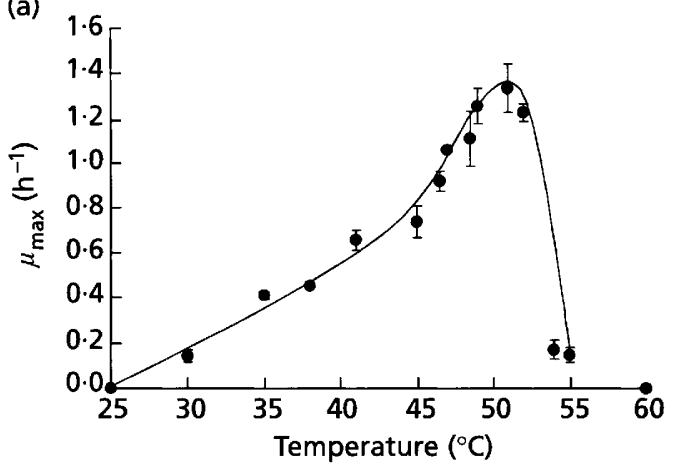

(b)

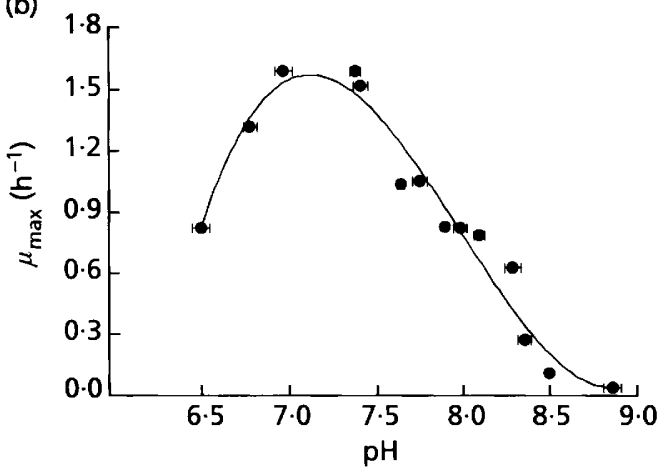

Fig. 2. Effect of (a) temperature and (b) $\mathrm{pH}$ on growth as determined by the growth rate $(\mu)$ of strain $\mathrm{Wv}^{\top}{ }^{\top}$ grown on $\mathrm{RCM}$.

storage at $4{ }^{\circ} \mathrm{C}$ in air. Liquid batch cultures were carried out in half-filled universals, sealed and incubated statically. Growth on RCM occurred overnight, producing turbid cultures with $\mathrm{OD}_{600}$ of $>1.5 \mathrm{U}$ and an abundant amount of gas was produced. A copious amount of slime was produced during growth in RCM with $\mathrm{pH}$ values greater than $\mathrm{pH} 8 \cdot 0$. Growth occurred on PYG only in the presence of peptone, tryptone and yeast extract. The final $\mathrm{pH}$ of cultures grown on PYG and $\mathrm{RCM}$ at $45^{\circ} \mathrm{C}$ with initial $\mathrm{pH}$ values of $\mathrm{pH}$ 6-9 was pH 5.2-5.4 after $5 \mathrm{~d}$.

(ii) Temperature and $\mathrm{pH}$ range. Strain $\mathrm{Wv} 6^{\mathrm{T}}$ grew at $30-55^{\circ} \mathrm{C}$, but no growth was observed at $25-$ or $60^{\circ} \mathrm{C}$ after incubation for $4 \mathrm{~d}$. The optimum temperature for growth was $49-52{ }^{\circ} \mathrm{C}$, with growth rates of $1 \cdot 2-1 \cdot 5 \mathrm{~h}^{-1}$ (Fig. 2a). Temperature value determinations were repeated up to four times. Initial $\mathrm{pH}$ values of $\mathrm{pH}$ 5.9-9.9 supported growth, but no growth occurred at $\mathrm{pH} 5.7$ or $\mathrm{pH} 11 \cdot 1$. The optimum $\mathrm{pH}$, determined using controlled-batch culture (between $\mathrm{pH} 6.5$ and 8.9), was $\mathrm{pH} 7 \cdot 2 \pm 0 \cdot 2$, with growth rates of $1 \cdot 5-1 \cdot 6 \mathrm{~h}^{-1}$ (Fig. 2b).

(iii) Substrate utilization and acid production. Strain $\mathrm{Wv}^{\mathrm{T}}$ grew on PY broth supplemented with $(\%, w / v)$ : glucose, 1 ; sucrose, 1 ; fructose, 1 ; galactose, 1 ; lactose, 1 ; maltose, 1 ; mannose, 1 ; trehalose, 1 ; cellobiose, 1 ; starch, 1 ; amygdalin, $0 \cdot 5$; and sorbitol, 1 . In all cases except lactose, growth was accompanied by acid production. Neither growth nor acid production were detected on arabinose $(1 \%, \mathrm{v} / \mathrm{v})$, ribose $(0.5 \%, \mathrm{v} / \mathrm{v})$,

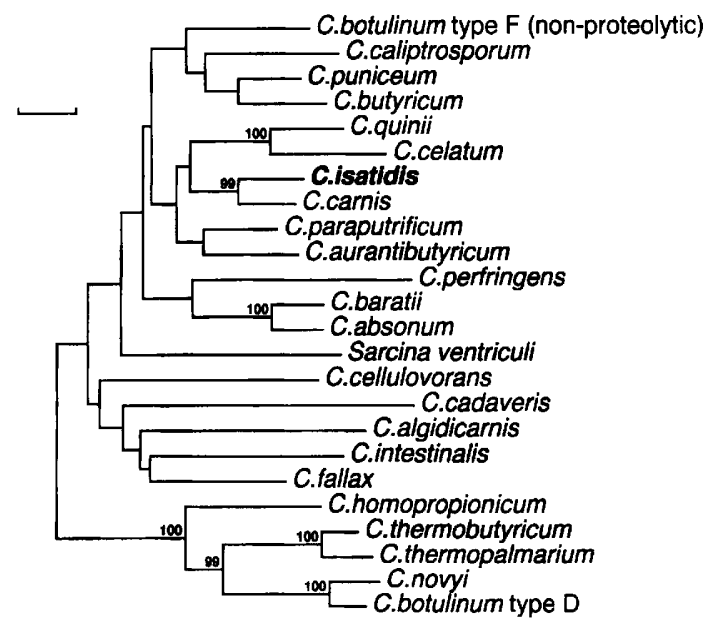

Fig. 3. Phylogenetic tree based on a comparison of ca. 1320 bases constructed using the neighbour-joining method, showing the position of $C$. isatidis strain $W_{v \sigma^{\top}}$ amongst some close relatives within rRNA cluster I Clostridium [see Collins et al. (1994) for rRNA group designation]. Bootstrap values $>90 \%$ (expressed as percentages of 500 replications) are shown at the branching points. Bar, $1.2 \%$ base substitutions.

raffinose $(1 \%, \mathrm{v} / \mathrm{v})$, rhamnose $(1 \%, \mathrm{v} / \mathrm{v})$, erythritol $(0.5 \%, \mathrm{v} / \mathrm{v})$, glycerol $(0.8 \%, \mathrm{v} / \mathrm{v})$, mannitol $(1 \%)$ or inulin $(1 \%, v / v)$. Strain $\mathrm{Wv}^{\mathrm{T}}$ produced acid from salicin but not from xylose, melezitose or glycogen (growth not tested with these substrates).

(iv) Biochemical properties. Strain $\mathrm{Wv}^{\mathrm{T}}$ hydrolysed aesculin but not starch or gelatin. Indole was not produced from tryptophan, and catalase, lecithinase and urease were absent. Litmus milk was not clotted and meat was not digested by the isolate. Nitrate was not reduced to nitrite. Strain $\mathrm{Wv} 6^{\mathrm{T}}$ was sensitive to tetracycline $\left(30 \mu \mathrm{g} \mathrm{disc}{ }^{-1}\right)$ and gentamicin $(10 \mu \mathrm{g}$ $\left.\operatorname{disc}^{-1}\right)$, but not erythromycin $\left(5 \mu \mathrm{g} \mathrm{disc}^{-1}\right)$. Growth in liquid broth cultures was inhibited by penicillin ( 2 unit $\left.\mathrm{ml}^{-1}\right)$, ampicillin $\left(30 \mu \mathrm{g} \mathrm{ml}^{-1}\right)$, rifampicin $\left(30 \mu \mathrm{g} \mathrm{ml}^{-1}\right)$ or tetracycline $\left(6 \mu \mathrm{g} \mathrm{ml}^{-1}\right)$, but occurred in the presence of chloramphenicol $\left(30 \mu \mathrm{g} \mathrm{ml}^{-1}\right)$ and kanamycin $(30 \mu \mathrm{g}$ $\mathrm{ml}^{-1}$ ).

(v) Fermentation products of PYG. During growth on PYG, strain $\mathrm{Wv}^{\mathrm{T}}$ produced an abundant amount of gas, which was identified as carbon dioxide and hydrogen. These gases were present in the ratio of $3: 4$. The main organic acids identified using HPLC were acetic, lactic and formic acids. Small amounts of ethanol were also produced.

\section{5 rRNA sequence analysis}

To investigate the phylogenetic interrelationships of the isolates, genes encoding $16 \mathrm{~S}$ rRNA were amplified by PCR and subjected to sequence analysis. A short stretch of ca. 500 nucleotides (proximal to the 5 ' end of the rRNA, which included diagnostic variable regions V1 to V3) was determined and the isolates were found to be genealogically homogeneous, exhibiting identical 
Table 1. Similarity values based on the 165 rRNA sequences of some Clostridium species

\begin{tabular}{|c|c|c|}
\hline Species & EMBL no. & $\begin{array}{c}\text { Similarity (\%) with } \\
\text { strain } \mathrm{Wv6}^{\mathrm{T}}\end{array}$ \\
\hline C. absonum & X77842 & 94.9 \\
\hline C. algidicarnis & $X 77676$ & $92 \cdot 1$ \\
\hline C. aurantibutyricum & X68183 & $96 \cdot 1$ \\
\hline C. baratii & $\mathrm{X} 68175$ & $95 \cdot 3$ \\
\hline C. botulinum (type D) & X68187 & $92 \cdot 0$ \\
\hline C. botulinum (type $\mathrm{F})^{*}$ & X68171 & $94 \cdot 3$ \\
\hline C. butyricum & X68178 & $94 \cdot 2$ \\
\hline C. cadaveris & M59068 & $92 \cdot 5$ \\
\hline C. caliptrosporum & X77843 & $94 \cdot 6$ \\
\hline C. carnis & M59091 & $97 \cdot 8$ \\
\hline C. celatum & X77844 & 96.9 \\
\hline C. cellulovorans & X71849 & $94 \cdot 4$ \\
\hline C. fallax & M59088 & $93 \cdot 2$ \\
\hline C. homopropionicum & X76744 & $92 \cdot 4$ \\
\hline C. intestinalis & $X 76740$ & $93 \cdot 2$ \\
\hline C. novyi & X68188 & $91 \cdot 5$ \\
\hline C. paraputrificum & X75907 & $95 \cdot 8$ \\
\hline C. perfringens & M59103 & $93 \cdot 7$ \\
\hline C. puniceum & X73444 & $94 \cdot 6$ \\
\hline C. quinii & $X 76745$ & $96 \cdot 2$ \\
\hline C. thermobutyricum & X72868 & 91.9 \\
\hline C. thermopalmarium & X72869 & $91 \cdot 7$ \\
\hline Sarcina ventriculi & X76649 & $93 \cdot 3$ \\
\hline
\end{tabular}

* Non-proteolytic. sequences. The almost complete $16 \mathrm{~S}$ rRNA gene sequence of a representative strain (strain $\mathrm{Wv} 6^{\mathrm{T}}$ ) of the indigo-reducing bacterium was therefore determined. Preliminary comparative sequence searches of EMBL and GenBank databases using the FASTA program (Devereux et al., 1984) revealed the unknown bacterium was related to the Clostridium subphylum of the Gram-positive bacteria. Within this subphylum, highest sequence relatedness (generally $>92 \%$ similarity) was shown with rRNA cluster I Clostridium [rRNA clusters as defined by Collins et al. (1994)]. Significantly lower levels of relatedness were shown with members of the other Clostridium rRNA clusters (data not shown). The new sequence and those of its closest relatives in rRNA cluster I Clostridium were subjected to pairwise analysis and derived evolutionary distances were used to determine their phylogenetic interrelationships. The phylogenetic analysis confirmed that the unknown bacterium was a member of rRNA cluster I Clostridium. A tree depicting the phylogenetic relationships of strain $\mathrm{Wv}^{\mathrm{T}}$ is shown in Fig. 3 and some representative sequence similarities are given in Table 1. C. carnis was shown to be the closest phylogenetic relative of strain $\mathrm{Wv} 6^{\mathrm{T}}$. A pairwise sequence divergence value of ca. $2 \cdot 4 \%$ (corresponding to 30 differences in 1323 bases) showed that the unknown bacterium, although highly related to $C$. carnis, is however, a phylogenetically separate species.

Distinguishing physiological and biochemical properties of the clostridial species that are closely related to

Table 2. Distinguishing physiological properties of $C$. isatidis and five closely related clostridia from rRNA cluster I

Data from Cato et al. (1986) and Svensson et al. (1992). Strains: 1, C. isatidis; 2, C. carnis; 3, C. celatum; 4, C. quinii; 5, C. aurantibutyricum; 6 , C. paraputrificum.

\begin{tabular}{|c|c|c|c|c|c|c|}
\hline Character & 1 & 2 & 3 & 4 & 5 & 6 \\
\hline Morphology & $\begin{array}{l}\text { Straight or } \\
\text { curved } \\
\text { rod }\end{array}$ & $\begin{array}{l}\text { Straight or } \\
\text { curved } \\
\text { rod }\end{array}$ & $\begin{array}{l}\text { Straight or } \\
\text { curved } \\
\text { rod }\end{array}$ & $\begin{array}{l}\text { Rod then } \\
\text { ovoid }\end{array}$ & Straight rod & $\begin{array}{l}\text { Straight or } \\
\text { curved rod }\end{array}$ \\
\hline Size $(\mu \mathrm{m})$ & $0.3-0.6 \times 1 \cdot 8-9 \cdot 1$ & $0.5-1.1 \times 1.6-9.9$ & $0.8-3 \cdot 0 \times 6 \cdot 3$ & $1-6 \times 2 \cdot 5-10$ & $0.5-0.8 \times 2.8-6.3$ & $0.5-1.4 \times 1.9-17$ \\
\hline Occurrence & $\begin{array}{l}\text { Singly, pairs or } \\
\text { chains }\end{array}$ & Singly or pairs & $\begin{array}{l}\text { Singly, pairs or } \\
\text { chains }\end{array}$ & Singly & Singly or pairs & Singly or pairs \\
\hline Endospores & Oval terminal & $\begin{array}{l}\text { Oval terminal or } \\
\text { subterminal }\end{array}$ & $\begin{array}{l}\text { Oval terminal, } \\
\text { subterminal or } \\
\text { central }\end{array}$ & Long central & Oval subterminal & Oval terminal \\
\hline Motility & + & $+1-$ & - & + & + & $+1-$ \\
\hline pH range* & $5.9-9.9(7.2)$ & $\begin{array}{c}\text { NK; no growth at } \\
8.5\end{array}$ & NK & $6 \cdot 2-10 \cdot 5(7 \cdot 4)$ & NK & NK \\
\hline $\begin{array}{l}\text { Temperature range } \\
\left({ }^{\circ} \mathrm{C}\right) \dagger\end{array}$ & $30-55(49-52)$ & $\begin{array}{c}30-37 \text { not } 25 \text { or } \\
45\end{array}$ & $\begin{array}{c}30-37 \text { not } 25 \text { or } \\
45\end{array}$ & $15-50(40)$ & $\begin{array}{c}30-37 \text { not } 25 \text { or } \\
45\end{array}$ & $\begin{array}{c}30-45 \text { but weak } \\
\text { at } 25\end{array}$ \\
\hline Respiration & $\begin{array}{c}\text { Anaerobic but } \\
\text { aerotolerant }\end{array}$ & $\begin{array}{l}\text { Anaerobic but } \\
\text { aerotolerant }\end{array}$ & & Strictly anaerobic & & \\
\hline $\mathrm{G}+\mathrm{C}(\mathrm{mol} \%)$ & 27 & 28 & NK & 28 & 27 & $26-27$ \\
\hline
\end{tabular}

NK, Not known.

* Optimum pH for growth given in parentheses.

$\dagger$ Optimum temperature for growth given in parentheses. 
Table 3. Distinguishing biochemical properties of $C$. isatidis and five closely related clostridia from rRNA cluster I

Data from Cato et al. (1986) and Svensson et al. (1992). Strains: 1, C. isatidis; 2, C. carnis; 3, C. celatum; 4, C. quinii; 5, C. aurantibutyricum; 6, C . paraputrificum . + , Positive for $90-100 \%$ strains; - , negative for $90-100 \%$ strains; $+/-, 61-89 \%$ strains positive; $-/+, 11-39 \%$ strains positive; $d, 40-60 \%$ strains positive; $w$, weak reaction.

\begin{tabular}{|c|c|c|c|c|c|c|}
\hline Character & 1 & 2 & 3 & 4 & 5 & 6 \\
\hline Starch hydrolysed & - & - & - & - & + & + \\
\hline Nitrate to nitrite & - & - & d & - & + & $-/+$ \\
\hline Gelatin hydrolysed & - & - & - & - & + & - \\
\hline Urease & - & NK & + & - & NK & NK \\
\hline $\begin{array}{l}\text { Products from } \\
\text { PYG* }\end{array}$ & ALF2 & BALF (S) & AFB2 (S) & FABL2 & LBA & BAL (SF) \\
\hline Milk reaction $\dagger$ & - & - & $\mathrm{c}$ & NK & c & $\mathrm{c}$ \\
\hline Indigo reduced & + & + & - & - & - & $\mathrm{NK}$ \\
\hline \multicolumn{7}{|l|}{$\begin{array}{l}\text { Antibiotic } \\
\text { resistance: }\end{array}$} \\
\hline Chloramphenicol & + & - & - & $\mathrm{NK}$ & - & $1 / 39 \ddagger$ \\
\hline Erythromycin & + & - & - & NK & - & $13 / 39 \ddagger$ \\
\hline Penicillin & - & - & - & NK & - & $3 / 39 \ddagger$ \\
\hline Tetracycline & - & - & - & NK & - & $3 / 39 \ddagger$ \\
\hline \multicolumn{7}{|l|}{ Acid from: } \\
\hline Amygdalin & + & $\mathrm{w}$ & + & $\mathrm{NK}$ & - & d \\
\hline Arabinose & - & - & - & NK & w & - \\
\hline Fructose & + & d & + & + & + & + \\
\hline Galactose & + & d & + & + & $\mathrm{w}$ & + \\
\hline Glycogen & - & - & - & NK & w & $+1-$ \\
\hline Inulin & - & - & - & $\mathrm{NK}$ & - & - \\
\hline Lactose & - & d & + & - & + & + \\
\hline Mannitol & - & - & - & + & - & - \\
\hline Mannose & + & $\mathrm{w}$ & + & + & w & + \\
\hline Melezitose & - & - & - & $\mathrm{NK}$ & - & - \\
\hline Raffinose & - & - & - & + & + & - \\
\hline Ribose & - & - & $\mathrm{d}$ & - & - & w- \\
\hline Sorbitol & + & - & - & - & - & - \\
\hline Starch & + & w & - & - & w & + \\
\hline Trehalose & + & - & + & NK & - & $-1+$ \\
\hline Xylose & - & - & - & + & - & - \\
\hline
\end{tabular}

NK, Not known.

* A, Acetic acid; B, butyric acid; F, formic acid; L, lactic acid; S, succinic acid; 2, ethanol. Products given in parentheses are irregular (minor and/or not present in all strains studied).

†c, Curd.

$\ddagger$ Number of strains positive out of total number of strains tested.

strain Wv6 ${ }^{\mathrm{T}}$, namely C. carnis, C. celatum, C. quinii, $C$. aurantibutyricum and Clostridium paraputrificum, are listed in Tables 2 and 3. All species are Gram-positive, do not produce indole or digest meat, are lecithinasenegative, hydrolyse aesculin and produce acid from glucose, maltose, cellobiose, sucrose and salicin, but not from rhamnose (Cato et al., 1986; Svensson et al., 1992). All species produce an abundant amount of hydrogen during growth and fail to grow in $6.5 \%$ $\mathrm{NaCl}$ (except $C$. quinii which is unknown) (Cato et al., 1986). All strains occur as straight or curved rods with the exception of $C$. quinii which becomes ovoid in older cultures (Svensson et al., 1992). The morphological, biochemical and physiological characteristics of strain
$\mathrm{Wv}^{\mathrm{T}}$ as well as the $16 \mathrm{~S}$ rRNA sequence analysis illustrates that strain $\mathrm{Wv}^{\mathrm{T}}$ is a new species of the genus Clostridium, for which the name Clostridium isatidis is proposed.

\section{Description of Clostridium isatidis sp. nov.}

Clostridium isatidis (i.sa'ti.dis. Gr. gen. n. isatidis of the crucifer plant Isatis).

Colonies are creamy white, mucoid, circular to irregular and low convex or raised to a central point. Cells are rod-shaped $(0 \cdot 3-0.6 \mu \mathrm{m}$ by $1 \cdot 8-9 \cdot 1 \mu \mathrm{m})$ and occur singly, in pairs or in chains. Oval terminal 
endospores are produced. The temperature range for growth is $30-55^{\circ} \mathrm{C}$, with an optimum temperature of $49-52{ }^{\circ} \mathrm{C}$. The $\mathrm{pH}$ range is initial $\mathrm{pH} 5 \cdot 6-9.9$ with an optimum $\mathrm{pH} 7 \cdot 2 \pm 0 \cdot 2$ (in controlled-batch culture). At $50^{\circ} \mathrm{C}$ and $\mathrm{pH} 7 \cdot 2 \pm 0 \cdot 2$, the doubling time is $26 \mathrm{~min}(\mu$, $1.6 \mathrm{~h}^{-1}$ ). Cultures hydrolyse aesculin. Acid is produced from amygdalin, cellobiose, fructose, galactose, glucose, maltose, mannose, salicin, sorbitol, sucrose, starch and trehalose. Acetic, lactic and formic acids, ethanol, carbon dioxide and hydrogen are produced during growth on PYG. The $\mathrm{G}+\mathrm{C}$ content of strain $\mathrm{Wv} 6^{\mathrm{T}}$ is $27 \mathrm{~mol} \%$. Isolated from woad vat. Type strain is strain $\mathrm{Wv6}^{\mathrm{T}}\left(=\mathrm{NCFB} 3071^{\mathrm{T}}\right)$.

\section{ACKNOWLEDGEMENTS}

This work was supported by a grant from the Leverhume Trust. Special thanks to Anthony Wynne (Institute of Food Research, Reading) for assistance with HPLC and Daniel Davies and Jason Osman (Food Science and Technology, Reading University) for assistance with fermentation assembly.

\section{REFERENCES}

Boddinghaus, B., Wolters, J., Heikens, W. \& Bottger, E. C. (1990). Phylogenetic analysis and identification of six different serovars of Mycobacterium intracellulare at the molecular level. FEMS Microbiol Lett 70, 197-204.

Cato, E. P., George, W. L. \& Finegold, S. M. (1986). Genus Clostridium. In Bergey's Manual of Systematic Bacteriology, vol. 2, pp. 1141-1200. Edited by P. H. A. Sneath, N. S. Mair, M. E. Sharpe \& J. G. Holt. Baltimore: Williams \& Wilkins.
Clark, R. J. H., Cooksey, C. J., Daniels, M. A. M. \& Withnall, R. (1993). Indigo, woad, and Tyrian Purple: important vat dyes from antiquity to the present. Endeavour 17, 191-199.

Collins, M. D., Lawson, P. A., Willems, A., Cordoba, J. J., Fernandez-Garayzabal, J., Garcia, P., Cai, J., Hippe, H. \& Farrow, J. A. E. (1994). The phylogeny of the genus Clostridium: proposal of five new genera and eleven new species combinations. Int $J$ Syst Bacteriol 44, 812-826.

Devereux, J., Haeberli, P. \& Smithies, O. (1984). A comprehensive set of sequence analysis programs for the VAX. Nucleic Acids Res 12, 387-395.

Felsenstein, J. (1989). PHYLIP - phylogeny inference package (version 3.2). Cladistics 5, 164-166.

Garvie, E. I. (1978). Streptococcus raffinolactis (Orla-Jensen and Hansen) a group N Streptococcus found in raw milk. Int J Syst Bacteriol 28, 190-193.

Harrigan, W. F. \& McCance, M. E. (1976). Laboratory Methods in Food and Dairy Microbiology. London: Academic Press.

Hurry, J. G. (1930). The Woad Plant and its Dye. London: Oxford University Press.

Kabdasli, I., Tünay, O. \& Orhon, D. (1995). Sulfate removal from indigo dyeing textile wastewaters. Water Sci Tech 32, 21-27.

Lawson, P. A., Gharbia, S. E., Shah, H. N. \& Clark, D. R. (1989). Recognition of Fusobacterium nucleatum, subgroups Fn-1, Fn2 and Fn-3 by ribosomal RNA gene restricted patterns. FEMS Microbiol Lett 65, 41-46.

Svensson, H., Dubourguier, H. C., Presier, G. \& Zehnder, A. J. B. (1992). Clostridium quinii sp. nov., a new saccharolytic anaerobic bacterium isolated from granular sludge. Arch Microbiol 157, 97-103. 